УДК 351.77

DOI https://doi.org/10.32838/TNU-2663-6468/2020.5/18

\title{
Автомсенко А.I.
}

здобувач кафедри економічної безпеки,

публічного управління та адміністрування

Державного університету «Житомирська політехніка»

\section{АНАЛІЗ СФЕРИ ГРОМАДСЬКОГО ЗДОРОВ'Я В УМОВАХ ЕПІДЕМІОЛОГІЧНИХ ЗАГРОЗ}

Громадське здоров'я є одним із найважливіших атрибутів суспільного життя та одним із основних показників його добробуту й розвиненості. Для успішної реалізації реформ у системі охорони здоров'я в Украӥні необхідна чітка, а також збалансована програма, формулювання усіх напрямів з урахуванням необхідності приведення низки законодавчих актів до потреб у даній сфері, зокрема прийняття Закону «Про систему громадського здоров'я», який є лише формі проекту. На даному етапі сфера громадського здоров'я перебуває під тиском глобальної епідеміологічної кризи, яка посилилася наприкіниі XX століття. Надзвичайні ситуації в сфері охорони здоров'я знаходяться серед найсерйозніших ризиків для глобальної безпеки. Україна повинна переорієнтувати фокус системи охорони здоров'я від політики лікування до політики зміинення здоров'я й попередження хвороб, на що й покликана розбудова системи громадського здоров'я в Украӥні. Окрім иього, законодавство у сфері санепідблагополуччя системно не переглядалось майже 30 років і потребує комплексної модернізації. На нашу думку, засвоєння сучасних моделей управління реформами слугує імпульсом для запровадження реформ та переходу системи охорони здоров'я на нові механізми функиіонування, що є процесом запровадження нововведень з метою переходу від ідеальної моделі до моделі реальної, зважаючи на надзвичайні ситуаиї, глобальні виклики та епідеміологічну кризу, яка охопила всю систему громадського здоров'я у загальносвітовому масштабі у зв 'язку із пандемічним поширенням COVID-19. Забезпечення сфери громадського здоров'я та реформування у сфері охорони здоров 'я необхідно спрямовувати на зміцнення здоров'я всіх верств населення, збільшення тривалості активного життя, поліпшення демографічної ситуачії, підвищення якості і ефективності медико-санітарної допомоги, удосконалення фінансування і управління галуззю. Адже поліпшення здоров'я населення є інтегральним показником успішності функиіонування держави та всіх ї̈ інституиій. 3 огляду на те, що роль державного управління охороною здоров'я у формуванні громадського здоров'я та начіональної безпеки беззаперечна, потрібно вживати всіх необхідних заходів для управлінської ефективності та державницького підходу у вирішенні питань протидії загрозам міжнародного характеру у сфері охорони здоров'я та функиіонування налагодженої системи ичим загрозам в Украӥні.

Ключові слова: епідемія, державна політика, епідеміологічні загрози, громадське здоров 'я, сфера охорони здоров'я.

Постановка проблеми. Пандемії, надзвичайні ситуації в сфері охорони здоров'я і слабкість систем охорони здоров'я загрожують не тільки людськими втратами, але й є серйозними викликами для світової економіки й глобальної безпеки, оскільки не детермінуються державними кордонами і національними інтересами, а вразливість однієї людини робить незахищеними усіх.

Аналіз останніх досліджень та публікацій. Питання сфери громадського здоров'я в умовах епідеміологічних загроз досліджували: Ситник T.I., Hallingberg B., Rothkopf D., Комісаренко C. B., King Nancy M. P., Breeze R., Budowle B., Schutzer S., Owens M. T. Та інші.
Постановка завдання. Проаналізувати сфери громадського здоров'я в умовах епідеміологічних загроз.

Викладення основного матеріалу. Як інституційний суб'єкт щодо відтворення соціальнобіологічної детермінації суспільства, громадське здоров'я дає змогу проаналізувати антропоцентричну цінність людини в конкретних історичних умовах і розкриває сутність внутрішньоіндикативного ставлення людини до цінності життя та його досконалості через призму «фізичного добробуту» [1], який гарантується лише фізичним здоров'ям. Останнє як зовнішньоатрибутивна ознака буття людини слугує «своєрідним естетичним та соці- 
альним мірилом індивіда, критерієм його краси, громадянської зрілості, духовного розвитку, готовності віддати свої сили служінню державі» [2].

Громадське здоров'я характеризує певний стан суспільства, який визначає рівень його спроможності щодо реалізації біологічних та соціальних функцій, які забезпечують життєдіяльність громадян. Громадське здоров’я в такий спосіб є певною формою відображення відповідних соціальнопобутових умов та стану навколишнього середовища, які в інтегрованій взаємодії забезпечують ефективність функціонування соціальних інститутів, що в остаточному підсумку є передумовою сталого розвитку суспільства. Такий контекст ідентифікації громадського здоров'я є своєрідною «вимірювальною лінійкою» для обстеження показників якості життя громадян через рівень організації охорони здоров'я [1]. Це вказує також на те, що «рівень громадського здоров'я, виступаючи головною умовою відтворення високоякісного трудового потенціалу, $є$ адекватним показником соціально-економічної безпеки держави» [3].

Вкрай небезпечною практикою стало використання інфекційних агентів 3 неблагородними цілями, що є біологічними загрозами для сфери громадського здоров'я сучасності. Хоча біологічна та бактеріологічна зброя - це не винахід сучасності, адже мають трохи довшу історію, ніж свідоме вивчення людством мікроорганізмів. Наприклад, у 1300 р. татаро-монголи при облозі Каффи закидали трупи померлих від чуми за мури міста. Японці активно працювали в секторі розробки біологічної зброї в часи другої світової війни. То були ганебні сторінки в історії отримання мікробіологічних знань - із дослідженнями на людях, в яких було використано більш як 5 тисяч людей, близько 600, з яких померло. Внаслідок експериментів було заражено близько тисячі колодязів у китайських селах для вивчення розвитку спалахів холери та тифу. Японські літаки скидали на китайські міста бліх, заражених легеневою чумою. Спалахи, які виникли, тривали ще впродовж наступних років та спричинили загибель близько 30 тисяч людей [4, с. 195]. Як приклад досліджень, в США приводять експериментальне контамінування метрополітену Нью Йорку непатогенною бактерією Bacillus globigii, що моделювала потенційну атаку збудником сибірської виразки. Тому, у 1972 р. було ініційовано підписання Конвенції про біологічну зброю, яка зобов'язала всіх країнучасників утриматися від іiі розробки та застосування [5]. Однак, це не стало запорукою того, що учасники таки дотримуються своїх обіцянок.
Припускається, що деякі країни продовжують свої дослідження неофіційно. У той же час такі країни, як Північна Корея, Іран та Сирія цього не приховують. Порушення техніки безпеки при таких дослідженнях іноді можуть створюють прецеденти, що порушують їх «секретність». Наприклад, спалах сибірської виразки у Скатиренбурзі в 1979 р., коли всі жертви захворіли у вузькій зоні по напрямку вітру від місцевого військового об'єкту, дало підстави стверджувати про напрацювання цього збудника. Прикладом біологічних терористичних атак $є$ розсилання листів із спорами збудників сибірської виразки в 2001 році [6, с. 16].

До засобів масового ураження належить токсична і бактеріологічна (біологічна) зброя, де дія останньої грунтується на використанні хвороботворних властивостей бойових біологічних засобів - мікроорганізмів, здатних розмножуватися в організмах людей, тварин і рослин та спричиняти масові захворювання. До таких бактеріологічних засобів відносять віруси, бактерії, грибки і токсичні продукти їхньої життєдіяльності, використання яких можливе за допомогою заражених переносників (комах, гризунів) або у вигляді суспензій і порошків у боєприпасах. За відсутності ефективної системи гарантування безпеки (зокрема, біобезпеки) розширення в деяких державах мережі досліджень у галузі готовності до реагування на біологічні загрози може також становити загрозу [7]. Збільшення кількості лабораторій $з$ високим рівнем захисту та розширення спектра досліджуваних патогенів сприяють поширенню потенційно чутливих даних і знань. Це ускладнює алгоритм поводження з біологічними та хімічними речовинами подвійного призначення та становить велику небезпеку для всієї сфери громадського здоров'я.

В останні роки міжнародна спільнота спрямувала значні зусилля на аналіз ефективності дотримання національних законодавств, кодексів поведінки та етики, спостереження за хворобами та реагування на них, біозахист і біобезпеку. Так, Управління з питань роззброєння (Office for Disarmament Affairs - ODA) OOH ще у 2007 p. започаткувало створення Бази даних про біологічні інциденти (Bio-incident Database), як того вимагає Глобальна антитерористична стратегія $\mathrm{OOH}$ (UN Global Counter-Terrorism Strategy) 2006 р.[8]. Управління запросило від країн-членів ООН оновлення списку лабораторій і кваліфікованих фахівців, складеного у 1989 р., з метою надання Генеральному секретарю ООН можливостей з розслідування повідомлень про використання хімічної чи БЗ $[9$, с. 248]. 
Аналіз загроз та оцінка ризиків, пов'язаних iз запобіганням хімічному та біологічному тероризму, реагуванням на їх випадки та ліквідацією їх наслідків, а також оцінка ефективності здійснення заходів протидії характеризуються меншою інформативністю, ніж у разі традиційних військових загроз від звичайних озброєнь, зокрема, внаслідок браку достовірної відкритої інформації. Як наслідок - багато держав не зважають на прямі загрози хімічного та біологічного тероризму, особливо, в умовах визначення пріоритетів за обмежених ресурсів. Ще у травні 1986 р. Міністерство оборони США у доповіді комітету Палати представників Конгресу США підтвердило, що завдяки методам генної інженерії бактеріологічна війна стає ефективним варіантом бойових дій; також було зазначено, що нові досягнення в галузі біотехнологій дозволяють створювати практично необмежену кількість варіантів того, що можна назвати «речовинами із заданими властивостями». Особливо небезпечними в ході бактеріологічної війни можуть стати нові, невідомі медицині інфекційні захворювання, що є прямою масовою загрозою громадському здоров'ю. Засоби та методи захисту від них доведеться створювати в умовах ведення бойових дій [10, с. 426]. Та попри дані заходи, у 2007 році отримали широкого розголосу прорахунки в галузях біозабруднення та біобезпеки на об'єктах, де повинні були дотримуватися правила техніки безпеки при роботі з біологічним матеріалом: в Інституті здоров'я тварин (Institute of Animal Health - IAH), де живий вірус ящуру в обмеженій кількості використовують для експериментів, а також на двох приватних біотехнологічних підприємствах «Merial Animal Health Ltd» та «Stabilitech Ltd», які виробляли у великій кількості вакцину проти ящуру та використовували в невеликій кількості живий вірус ящуру, подібний до того, який вироблявся у ІАН. Штам ящуру, виявлений під час розслідування інциденту на фермах поблизу міста Пірбрайт у графстві Суррей (Велика Британія), де було зафіксовано спалах ящуру, був ідентичний штаму, отриманому під час епідемії ящуру у Великій Британії у 1967 р. Саме цей штам широко використовують у дослідних лабораторіях та фармацевтичному виробництві, зокрема, на об'єктах у Пірбрайті. Таким чином, розслідування привело на вищенаведені об'єкти у Пірбрайті [11, с. 129].

Разом із виробленими механізмами протидії та безпеки, розвитком мікробіологічних та медичних технологій справжнім викликом цивілізаційного масштабу наприкінці 2019 року стало розповсюдження вірусу COVID-19. Із найбільш серйозних викликів біобезпеці та сфері громадського здоров'я за останніх 20 років становили: пташиний H5N1, H7N9 та свинячий H1N1 (a також: H5N8, H7N3, H7N7) віруси грипу, пріони, SARS, MERS, Ебола, віспа та поліомієліт, а також резистентні до ліків мікроорганізми (зокрема туберкульозу - M(X)DRTB) тощо. Та за розрахунками ВОО3 [7] та окремих авторитетних у світі науковців на початку XXI століття вказувалося на імовірність виникнення пандемії грипу в першій половині XXI століття як надзвичайно високу. Але справжньою «чумою» II половини XX ст. став ВІЛ / СНІД. Перший клінічний звіт про СНІД з'явився 5 липня 1981 року, у якому йшлося про п'ять випадків зараження в США. На даний моментне не існує ліків чи вакцини проти вірусу. Хоча розроблені методи терапії, які можуть уповільнити розвиток захворювання й дають пацієнтам змогу прожити нормальне і довше життя.

Вищенаведена таблиця чітко демонструє, що кількість людей, які живуть з ВІЛ у світі постійно зростає, але смертність навпаки зменшується. Політика боротьби 3 поширенням даного захворювання та фінансове забезпечення відповідних заходів у сфері громадського здоров'я призвели до позитивної динаміки, адже кількість нових випадків зменшується, а частка носіїв захворювання, що отримує антиретровірусну терапію (складова медичної допомоги хворим на ВІЛ) збільшується.

За даними 2019 року частка таких хворих (що отримує таку терапію) досягла значення $66,8 \%$ порівняно з 2,3 \% від усіх хворих за даними 2000 року.

Справжньою цивілізаційною загрозою, навіть, катастрофою став розвиток пандемії COVID-19. 1 липня 2020 р. Всесвітня організація охорони здоров'я (BOO3) оголосила про пандемію COVID19 , але масового поширення дане вірусне захворюваннями країнами світу набуло від початку 2020 року. Тому, локальний спалах коронавірусу в Китаї у місті Ухань на початковому етапі не сприймався, як небезпека світового рівня. Попри це, на сьогодні, від листопада-грудня 2019 року (коли уряд Китаю офіційно оприлюднив інформацію про спалах даного вірусу, хоча у новому дослідженні Гарвардської медичної школи йдеться про те, що супутникові знімки парковок біля лікарень в китайському Ухані, а також тенденції пошукових запитів в Інтернеті вказують, що новий коронавірус міг ширитися Китаєм ще в серпні минулого року), вірус поширився на всіх континентах світу та набув загрозливих пандемічних і мутованих форм. (табл. 1) 
Характеристика поширення COVID-19 в світі з початку 2020 року

\begin{tabular}{|c|c|c|c|c|c|c|c|c|c|}
\hline \multirow[b]{2}{*}{ Показник } & \multicolumn{9}{|c|}{ Місяць (2020 року) } \\
\hline & 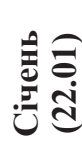 & 恣 & 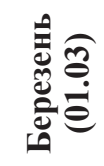 & 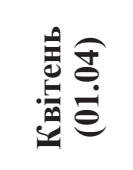 & 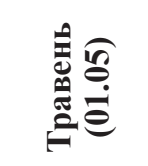 & 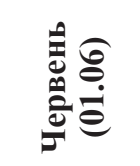 & 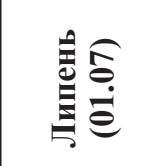 & 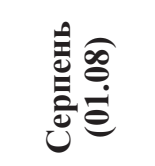 & 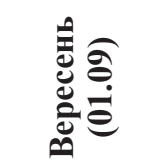 \\
\hline Виявлено & 555 & 12038 & 88369 & 933010 & 3345558 & 6229408 & 10537651 & 17673111 & 25580318 \\
\hline Померло & 17 & 259 & 2996 & 49684 & 238619 & 373973 & 512673 & 681133 & 852660 \\
\hline Одужало & 28 & 284 & 42710 & 192948 & 1052165 & 2672161 & 5394875 & 10372671 & 16879667 \\
\hline Хворіє & 510 & 11495 & 42663 & 690378 & 2054774 & 3183274 & 4630103 & 6619307 & 7847991 \\
\hline
\end{tabular}

Наростання темпів поширення пандемії відбувається дуже швидко, що пов'язано $з$ формами передачі вірусу.

Усвідомлюючи всі загрози пандемії COVID19 , уряди більшості країн застосували карантинні заходи, починаючи від середини березня 2020 року, які тривають по сьогодні. Внаслідок чого, виникла складна глобальна криза економічного та соціально-гуманітарного масштабу. Вся складність «війни» людства із COVID-19 грунтується на тому, що його походження є невизначеного генезу. Адже, китайський тоталітарний уряд надалі приховує інформацію та дані про виникнення і поширення цього небезпечного вірусу, попри те, що сьогодні світова спільнота усвідомлює, що широке застосування БЗ, може спричинити загибель всього живого на планеті. Крім того, не можна відкидати можливості використання цієї зброї в локальних конфліктах, терористами тощо. За цієї умови набувають значення, як єдині адекватні заходи із запобігання поширенню бактеріологічної та токсичної зброї у країнах, які iii раніше не мали, оскільки це не менш важливе завдання, ніж нерозповсюдження ядерної зброї.

Іншим аспектом даної коронавірусної кризи, на думку, академіка Михайла Тукала, відомого у світі молекулярної біології, директора Інституту молекулярної біології та генетики (ІМБіГ), в Україні почали більше дослухатися до науковців. Адже «Наука, зокрема і ті іiі напрямки, які завтра стануть головними для біобезпеки країни, держава майже не фінансує» [12]. Академік стверджує, «що в Україні давно треба створити центр з вивчення патогенів людей і тварин. Єдиний центр, де би працювали кращі фахівці різних інститутів - молекулярні біологи, вірусологи, генетики, імунологи. Важливо, що в країні є чимало «музеїв» - у Харкові, Одесі, Львові, Києві. «Музеями» називають зібрання зразків страшних патогенних вірусів і бактерій. Власне, це музеї згубних вірусів, деякі зразки датовані ще кінцем XIX століття, i вони стали би в нагоді для боротьби 3 новітніми вірусами. В нашій країні ще $\epsilon$ золотий кадровий потенціал, який варто використовувати на повну потужність, адже виникають нові й нові біологічні загрози, порівняно з якими коронавірус видається зовсім не страшним» [12]. Академік Тукало М. констатує те, що світ стрімко змінився і стрімко змінюватиметься надалі. Адже від глобалізації людство переходить до регіоналізації й навіть до ізоляціонізму та у цьому новому світі кожна країна захищатиме свою сферу громадського здоров'я самотужки.

Тому для України стратегічно важливою $\epsilon$ власна національна стратегія підтримки та захисту сфери громадського здоров'я. Тим більше, Розпорядженням КМУ від 30 листопада 2016 р. № 1002-р схвалено Концепцію розвитку системи громадського здоров'я [13], у якій вказано, що через розгалуженість і нескоординованість системи громадського здоров'я не виконують на належному рівні ММСП, імплементація яких у систему охорони здоров'я країни є частиною зобов'язань щодо європейської інтеграції України, тому на часі прийняття закону про систему громадського здоров'я в Україні.

Законодавство у сфері санепідблагополуччя системно не переглядалось майже 30 років і потребує комплексної модернізації. За цей час відбулося багато змін: по-перше, змінилися міжнародні підходи в цій сфері та безпосередньо підходи ВООЗ до забезпечення санітарного й епідемічного благополуччя у світі та Європейському регіоні ВООЗ шляхом формування законодавства про громадське здоров'я, яке базується на принципах пріоритетності збереження здоров'я людини та безпечності середовища іiі життєдіяльності; по-друге, Україна підписала Угоду про асоціацію з СС та взяла на себе низку міжнародних зобов'язань: у частині гармонізації положень національного законодавства, у сфері санепідблагополуччя i громадського здоров'я 3 
вимогами відповідних правових актів СС; по-третє, проведена Урядом у 2014 році оптимізація системи центральних органів виконавчої влади, у ході якої було ліквідовано Державну санітарно-епідеміологічну службу, відбулася без внесення змін до Закону України «Про забезпечення санітарного та епідемічного благополуччя населення〉 й інших законів, що регулюють відповідні правовідносини органів влади та суб'єктів господарювання.

Висновки. 3 огляду на вищевикладене, можна зробити наступні висновки:

- система реагування та протидії надзвичайним ситуаціям у сфері охорони здоров'я як на міжнародному, так і на національному рівні та іiі ефективність - це питання національної безпеки та національних інтересів кожної держави й світу загалом;

- інфекційні хвороби є загальномедичною проблемою, яка потребує більшої уваги з боку держави й органів охорони здоров'я;
- потребують термінового вирішення питання біологічної безпеки та біологічного захисту, особливо в контексті нових ризиків, що виникають у глобалізованому світі, та в контексті оборони й безпеки;

- потребує оновлення національне законодавство 3 питань санітарного й епідемічного благополуччя;

- на часі законодавче закріплення засад державної політики у сфері громадського здоров'я та прийняття закону про систему громадського здоров'я, оскільки $є$ Проект Закону «Про систему громадського здоров’я» № 4142 [14], який є актуальним для забезпечення системної, ефективної профілактики та боротьби як з інфекційними хворобами, що несуть ризик масового поширення, так і з масовими неінфекційними хворобами (отруєннями), виникнення яких зумовлено впливом біологічних, фізичних, хімічних чи соціальних факторів середовища життєдіяльності.

\section{Список літератури:}

1. Ситник T.І. Вплив факторів соціально-економічної невизначеності в період епідеміологічних загроз на державну політику підтримки та стабілізації діяльності бізнесу. Державне управління: удосконалення та розвиток. 2018. № 1. URL: www.dy.nayka.com.ua/pdf/7_2018/92.pdf.

2. Hallingberg B. Do stronger school smoking policies make a difference? Analysis of the health behaviour in school-aged children survey. The European Journal of Public Health. 2016. URL: http://www.shrn.org.uk/2016publications/.

3. The Social Medicine Reader: Social and Cultural Contributions to Health, Difference and Inequality / Henderson Gail E. (Ed.). Durham, NC : Duke University Press, 2015. Vol. 2. URL: https://www.dukeupress.edu/ the-socialmedicine-reader-second-edition.

4. Rothkopf D. Superclass: The Global Power Elite and the World They Are Making. Farrar, Straus and Giroux; 1 edition. 2009. 408 p.

5. Комісаренко С. В. Про біологічні загрози і біозахист. Українське слово: інтернет-видання. 2009. URL: http://ukrslovo.org.ua/svit/bezpeka/sergij-komisarenko-pro-biologichni-zagrozy-i-biozachyst.html

6. The Australia Group. Fighting the spread of chemical and biological weapons. 2007. 20 p. URL: http:// www.australiagroup.net/en/agb july2007.pdf.

7. World Healh Organization (2010). Pandemic (H1N1) 2009. URL: https://www.who.int/csr/don/2010 08 06/en/.

8. King Nancy M. P. Social Medicine Reader: Patients, Doctors and Illness. Durham, NC: Duke University Press, 2005. Vol. 1. URL: http://eprints.utas.edu.au/20795/1/ whole_HylandJeanetteE_thesis.pdf.

9. Institute for Economics \& Peace (2015). Global Peace Index 2015: Measuring Peace, its causes and its economic value. URL: http://visionofhumanity.org/reports.

10. SIPRI Yearbook: World Armament and Disarmament. New-York: Oxford University Press, 2008. 516 p.

11. Breeze R., Budowle B., Schutzer S. Microbial Forensics. Elsevier Academic Press. San Diego, 2005. 448 p.

12. Owens M. T. In Defense of Classical Geopolitics / Naval War College Review-199. Vol. 52. No 4. URL: http://www.nwc.navy.mil/press/review/1999/autumn/art3-a99.htm.

13. Розпорядження КМУ (від 30 листопада 2016 р. № 1002-р) «Про схвалення Концепції розвитку системи громадського здоров'я». URL: https://www.kmu.gov.ua/ua/npas/249618799.

14. Проект Закону України «Про систему громадського здоров'я». URL: https://moz.gov.ua/ uploads/1/5636-pro_20180620_1.pdf.

\section{Avtomeenko A.I. ANALYSIS OF PUBLIC HEALTH IN THE CONDITIONS OF EPIDEMIOLOGICAL THREATS}

Public health is one of the most important attributes of public life and one of the main indicators of its wellbeing and development. Successful implementation of reforms in the health care system in Ukraine requires a clear and balanced program, formulation of all areas, taking into account the need to bring a number of 
legislative acts to the needs in this area, including the adoption of the Law "On Public Health» only in the form of a project. At this stage, the public health sector is under pressure from the global epidemiological crisis, which intensified in the late twentieth century. Health emergencies are among the most serious risks to global security. Ukraine needs to shift the focus of the health care system from treatment policy to health promotion and disease prevention policy, which is what the public health system in Ukraine is designed to do. In addition, legislation in the field of sanitation has not been systematically revised for almost 30 years and needs comprehensive modernization. In our opinion, the assimilation of modern models of reform management serves as an impetus for the implementation of reforms and the transition of the health care system to new mechanisms of functioning, which is a process of innovation to move from the ideal model to the real model, given emergencies, global challenges and epidemiological a crisis that has affected the entire public health system worldwide due to the pandemic spread of COVID-19. Public health and health care reform need to be aimed at strengthening the health of all segments of the population, increasing life expectancy, improving the demographic situation, improving the quality and efficiency of health care, and improving funding and governance. After all, improving the health of the population is an integral indicator of the success of the state and all its institutions. Given that the role of public health management in shaping public health and national security is indisputable, it is necessary to take all necessary measures for management efficiency and a state approach in addressing issues of international threats in the field of health and functioning established system for these threats in Ukraine.

Key words: epidemic, public policy, epidemiological threats, public health, health care. 